\title{
New provincial records for twelve ant species (Hymenoptera, Formicidae) from Finland
}

\author{
Michael I. Saaristo \\ Zoological Museum, University of Turku, SF-20500 Turku, Finland
}

Prior to the work of Collingwood (1979), no coherent list of ants on a provincial level has been presented from Finland. Also, since Collingwood, only a few new records have been published (Rosengren 1981, Vepsäläinen \& Pisarski 1982, Vepsäläinen et al. 1984, and Saaristo 1986).

Study of the vast undetermined, in-liquid ant collection of the Zoological Museum at the Turku University has, however, yielded several new provincial records. Some older unpublished records derived from the dry collection of the museum are also included. Furthermore, extensive ant collecting done by the author during the last four years has resulted in numerous new records on a provincial level. A map of the provinces is found inside the back cover of every odd-numbered issue of the journal.

Collectors are indicated in parentheses according to the following abbreviations: $\mathrm{OE}=\mathrm{O}$. Enckell, JH = J. Högmander, TI = T. Ilvessalo, SK = S. Koponen, UL = U. Laine, PL $=\mathrm{P} . \mathrm{T}$. Lehtinen, $\mathrm{RM}=\mathrm{R}$. Mannila, $\mathrm{HM}=\mathrm{H}$. Myrsky, VM $=\mathrm{V} .-\mathrm{M}$. Mukkala, $\mathrm{IO}=\mathrm{I}$. Oksala, $\mathrm{VR}=\mathrm{V}$. Rinne, $\mathrm{MS}=\mathrm{M}$. Saaristo, OS = O. Sorsakoski.

Myrmica rugulosa Nylander. - Kb: Joensuu, centre (694:64), 17.7.1987, nesting abundantly in the park near the riverbank (MS) and Liperi, Myllykylä (694:63), 17.7.1987, a few nests in sandbanks adjacent to the railway (MS).

M. sabuleti Meinert. - Al: Kumlinge, Enklinge (670:15 and 671:15) in 1971 and 1972 from a small bog 41 $\not \varnothing \not$ and in 1972 from a Corylus-grove one $\measuredangle$; all by pit-fall traps (PL, RM \& IO) and several nests during 27.7.-31.7.1988 from the following places: Lumparland, Krogstad (668:12), Sund, Bomarsund (669:12) and Stenrösbergen Stormyran (670:12), Finström, Bergö and Bamböle (670:10), and Kökar, Söderby (666:16) (MS). — St: Säkylä, Säkylänharju (677:26), 7.8.1988(VR) and Köyliö, Säkylänharju (678:25), 11.8.1988 (MS).

M. scabrinodis Nylander. - LkE: Sodankylä, Aartola in 1983, 31థo and $51 \Varangle ð ̧$ by pit-fall traps (SK).
M. schencki Emery. - Ka: Virolahti, Hurppu (671:54), 14.8.1985 (MS) and Ylämaa, Sammalinen (673:55), 31.5.1988 (MS). — St: Köyliö, Säkylänharju (678:26), 11.8.1988 (MS). — Sb: Joroinen, one $\measuredangle$ (no date) (OE). $K b$ : Liperi, Myllykylä (694:63), 20.8.1986 (MS).

M. sulcinodis Nylander. - St: Ikaalinen, Kovero (687:31), 23.4.1983,4ðð (PL), Vammala, Huhtala (680:28), 4.7.1986 (MS), and Köylio, Säkylänharju (678:25), 11.8.1988 (MS).

Leptothorax muscorum (Nylander). - Kb: Liperi, Ylämylly (694:63), 17.7.1987 (MS) and Nurmes, Puukari (707:58), 15.7.1987 (MS). — Oa: Lappfjärd, Algars (691:21), 12.7.1966, one $\measuredangle$ (PL) and Ilmajoki, 18.5.1985, one $\measuredangle$ (VM). —Om: Vimpeli, Vatpakka (700:34), 2.6.1988 (MS). - ObS: Hailuoto, Marjaniemi (721:38), 12.8.1985 (MS).

Harpagoxenus sublaevis (Nylander). - Al: Kumlinge, Enklinge (671:15) in 1971, one $\Varangle$ by pit-fall trap (PL) and several colonies with Leptothorax acervorum and/or $L$. muscorum slaves during 28.-30.7.1987 from the following places: Eckerö Torp Skeppsvik and Degersand (669:08), Finström, Bergö and Bamböle (670:10) and Bjärnström (669:10), Lumparland, Krogstad (668:12), and Sund, ${ }^{\circ} \mathrm{E}$ of Bomarsund (669:12) (MS). — Ka: Ylämaa, 4 km NE of the church (674:55), 13.8.1985, a nest with $L$. acervorum and $L$. muscorum slaves (MS) - St: Vammala, Lousaja (681:28), 27.7.1985 and 4.7.1986, two nests with $L$. acervorum slaves (MS). — Sa: Rautjärvi, Laikko (680:62), 13.8.1985, two nests with $L$. acervorum and $L$. muscorum slaves (MS). $K b$ : Liperi, Ylämylly (695:63), 17.7.1987, a nest with $L$. acervorum slaves (MS). - Om: Soini, Laasala (698:34), Lestijärvi, Järventausta (705:38), Reisjärvi, Katajaneva (705:39), Lohtaja, Vattajanniemi (710:32), Himanka, Rautila (711:33) and Torvenkylä (711:34), Kalajoki, Siipa (712:34), during 1.-3.6.1988 several nests with L. acervorum slaves (MS).

Formicoxenus nitidulus (Nylander), $-K b$ : Ilomantsi, Lyijyvaara, 14.6.1967, one $\varnothing$ and Pallosenvaara (701:70),

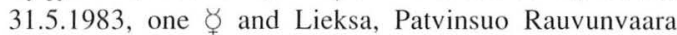
(701:68), 31.5.1984, 4ఫð and Koli Ipattivaara (700:64), 1.6.1984, 35ф๖ (PL).

Lasius mixtus (Nylander). —Al: Eckerö, Torp Skeppsvik (669:08): a small bog, in 1967, one o by pit-fall trap (MS) 
and Kumlinge, Enklinge (671:15), in 1972, one $q$ by pit-fall trap (PL, RM \& IO).

Formica cinerea Mayr. - St: Säkylä, Säkylänharju (677:26), 7.8.1988(VR) and Köyliö, Säkylänharju (678:25), 11.8.1988 (MS), numerous nests in a sandy terrain.

Formica fusca Linnaeus. - Al: Eckerö, Torp Skeppsvik (669:08): a small bog, in 1967, $5 \not \Varangle \succ\rceil$ by pit-fall traps (M. Saaristo leg.), Kumlinge, Enklinge (671:15): edge of a meadow, in 1972, one $\varnothing$ and $\not$ by pit-fall traps (PL, RM \& IO), and Kökar (666:16), 25.8.1975, one $\not$ (UL) and several nests during 28.-31.7.1987 from the following places: Eckerö, Torp Skeppsvik and Degersand (669:08), Hummelvik (670:08), and Överby (670:09), Finström, Bergö and Bamböle (670:10) and Tjudö (671:11), Lemland, Vessingboda (667:11), Lumparland, Krogstad (668:12), Vårdö, church village (669:13) and Sandö (670:13), Sund, Tosarby (669:11), Bomarsund (669:12), and Stenrösbergen (670:12), Kökar, ferry harbour (666:15), and Vålö (666:16) (MS).

F. pressilabris Nylander. - Ab: Korppoo, Jurmo Joutsenlampi (665:19) in 1969, one $\measuredangle$ by pit-fall trap (HM \& JH) and Uusikaupunki, Lyökki Ruotsinluoto (676:18), in 1973 and 1974 , over $500 \varnothing \varnothing$ by pit-fall traps (TI). - Om: Mustasaari, Raippaluoto Norra Valgrund (702:21): several nests on a bog, 31.5.1988 (MS).
F.pratensis Retzius. - Al: Mariehamn (668:10): a nest in a Sedum rupestre stand, 17.7.1983, some $\measuredangle \ngtr ॄ(\mathrm{PL})$ and

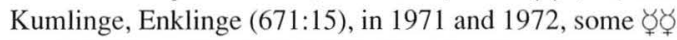
by pit-fall traps (PL, RM \& IO), Finström, Bergö (670:10), 28.7.1987 (MS) and Vårdö, Sandö (670:13), 29.7.1987 (MS). — Ka: Kotka, Lehmäsaari (670:49), 6.7.1988(VR). -ObN: Keminmaa, Kalkkimaa (671:38), 12.8.1986(MS).

\section{References}

Collingwood, C. A. 1979: The Formicidae (Hymenoptera) of Fennoscandia and Denmark. - Fauna Entomol. Scand. 8. 174 pp. Klampenborg.

Rosengren, R. 1981: En tredje fyndort av den svarta hästmyran Camponutus vagus (Scopoli) i sydvästra Finland (Formicidae). - Notulae Entomol. 61:227.

Saaristo, M. I. 1986: The fourth record of Sifolinia karavajevi (Arnoldi) (Hym., Formicidae) from the Nordic countries. - Notulae Entomol. 66:97-98.

Vepsäläinen, K. \& Pisarski 1982: Assembly of island ant communities. - Ann. Zool. Fennici 19:327-335.

Vepsäläinen, K., Pisarski, B., Kantorek, R. \& Laine, K. 1984: Formicidae (Hymenoptera) of Inari Lapland. Kevo Notes 7 (1984):115-116. 